\title{
Masculinidades plurais na América portuguesa (séculos XVI, XVII e XVIII)
}

\section{Plural masculinities in Portuguese America (XVI, XVII and XVIII centuries)}

\author{
Mário Martins Viana Júnior*
}

Resumo: Este artigo tem como propósito analisar masculinidades no processo de expansão do Império Ultramarino português, entre os séculos XVI e XVIII, conferindo centralidade ao avanço da colonização nas capitanias do Norte da América Portuguesa. Na primeira parte do trabalho focamos nosso exame sobre a dinâmica do masculino ideal e do ideal de masculinidade. Em seguida, analisamos a lei como plataforma delineadora dos gêneros. Por fim, cotejamos esses elementos ordenadores com as experiências de alguns dos sujeitos que ganharam destaque na aventura de colonização do Estado do Brasil, como o cavaleiro Diogo Botelho, oitavo Governador Geral do Estado do Brasil.

Palavras-chave: Masculinidade; colônia; américa portuguesa

\footnotetext{
* Professor Adjunto do Departamento de História da Universidade Federal do Ceará, setor de estudos História do Brasil. Possui doutorado em História Cultural (UFSC-2013) e mestrado em História Social (UFC-2009). Atualmente é um dos coordenadores do Núcleo de Estudos sobre Memória e Conflitos Territoriais (COMTER) e do projeto Memória das Comunidades Impactadas pelos Perímetros de Irrigação no Ceará. Tem experiência na área de História, com ênfase em História do Brasil, atuando principalmente nas seguintes temáticas e temporalidades:
} 
gênero, história das mulheres, masculinidades, América Portuguesa, Brasil República, semiárido, campesinato, conflitos territoriais, memórias do/no campo. E-mail: mario_ufc@ hotmail.com

\begin{abstract}
This article has the goal to analyse the masculinities in the expansion process of the Portuguese Ultramarine Empire between XVI and XVIII centuries, granting centrality to the advance of colonization in the North captaincies of the Portuguese America. In the first part of this work, we focus on examining the dynamics of masculine and ideal of masculinity. Afterwards, we analyse the law as an outlining platform of gender. Finally, we collate these ordering elements with the experiences of some subjects that gained importance in the colonizing adventure of the State of Brazil, as the knight Diogo Botleho, the eight General Governor of the State of Brazil.
\end{abstract}

Keywords: Masculinity; colony; portuguese america; império ultramarino; redes de negociação

\title{
O Império Ultramarino: redes de negociação
}

No século XVII, os domínios do Império ultramarino português constituíram ampla e complexa dilatação, interligando potentados que cruzavam três oceanos (Atlântico, Índico e Pacífico) e quatro continentes (América, África, Ásia e Europa). A partir das ações e experiências dos súditos régios no Reino e nos territórios coloniais foi tecida e mantida uma variedade de redes que interligavam potentados, desde o Brasil ao Japão.

Para a consecução da governabilidade sobre esses domínios, o monarca e seus ministros colocaram em pleno funcionamento uma lógica cuja denominação apresenta variações entre os historiadores (as): o sistema de mercês, a economia do dom ou a economia da benemerência. Revestindo-se de peculiaridades nos países ibéricos, na prática essa lógica implicou um complexo sistema de trocas em que o Reino retribuía os serviços régios dos súditos por meio da doação de honrarias, títulos e mercês, garantindo a manutenção de uma hierarquia social imbricada em um ethos nobiliárquico, um modelo de vida aristocrático que ressoava através de redes clientelares em todas as partes do Império.

Desde a ascensão da Época Moderna, os reis tentavam constantemente impor o princípio de autoridade aos seus súditos, mediante a administração do fisco, da justiça e da guerra, projetando-se como árbitros supremos. ${ }^{1}$ Nesses processos, além do sistema de mercês, a legislação expressa nas Ordenações do Reino (Afonsinas, Manuelinas e Filipinas) e nas Leis Extravagantes foi uma ferramenta importante que auxiliou nos processos de conformação e delineamento dos comportamentos, sexualidades e subjetividades daqueles 
que integravam o Império ultramarino e que buscavam projeções nele.

Houve uma dinâmica mais complexa para além da relação simplificada entre a metrópole dominante e a colônia dominado. Os parâmetros do Antigo Regime cruzaram os oceanos e atingiram os territórios coloniais, endossando o entendimento de que o Império ultramarino foi alavancado e mantido através de variadas formas de negociação. Ampla e diversa bibliografia mostra como a autoridade do monarca era negociada com outros indivíduos nos âmbitos econômico, político, social e militar. ${ }^{2}$

Entretanto, ainda são muito reduzidos os estudos que se dedicam a investigar e debater a miríade de possibilidades abertas entre as relações de gênero na América portuguesa. Diante da constatação da inexistência de um poder régio absoluto e da evidência de múltiplas formas de negociação propiciadas nos Estados Monárquicos, este artigo analisa como se criaram também inúmeras relações, apropriações, alterações, inversões entre outras questões no âmbito das relações de gênero, principalmente em torno das masculinidades no Brasil entre os séculos XVI, XVII e XVIII.

\section{Masculino Ideal e o ideal de masculinidade}

No forjar de uma identidade para os portugueses e no processo de construção do Estado dinástico, o Rei constituiu uma peça fundamental, estruturante e estruturada dessa sociedade. A partir do século XIV, o Monarca foi se tornando sinônimo de "res publica" (coisa pública) agregando funções e poderes próprios dessa transformação e se tornando o principal representante do Estado. Assim era dele não apenas o papel de gerir e garantir a defesa do Reino, e mais tarde do Império, mas de aplicar a Justiça aos seus súditos, de conferir graça e honrarias, de punir, de estabelecer guerra, enfim de garantir o bom funcionamento da ordem no Antigo Regime. No âmbito das relações de gênero atuava como uma importante força centrípeta.

Em nossa análise, o Rei se destacava como um "masculino ideal". Era ele quem ocupava o principal posto em uma hierarquia exclusivamente integrada por homens, concentrando poderes que interferiam direta e indiretamente na vida de seus súditos. O sistema de chancelas régias apontava isso claramente. O Monarca interpelava os sujeitos a agirem de acordo com as leis do Reino, subordinando os outros homens (e as mulheres), além de se apresentar como o principal administrador/controlador da violência. Era também o chefe da Casa Real e, consequentemente, de todas as outras casas. Colocava-se como pai dos súditos e era significado como a cabeça do corpo régio.

Os homens que ocupavam a cadeira de Monarca estavam acima de todos os outros homens e agiam de maneira ativa. Seus poderes se 
aplicavam de forma direta, como é possível observarmos nas inúmeras e diferentes cartas e decretos régios que tratavam de uma infinidade de temas relacionados ao engendramento ${ }^{3}$ dos comportamentos, tais como: a prisão e o envio de "homens vadios" para servir nas galés ${ }^{4}$, a proibição do "diálogo entre homens e mulheres" nas igrejas", as resoluções sobre os assassinatos cometidos no Reino e nas partes do Brasil. ${ }^{6}$ As Ordenações (Afonsinas, Manuelinas e Filipinas) eram testemunho dessa intervenção direta e auxiliavam na composição de uma cultura masculina idealizada. ${ }^{7}$

Segundo António Manuel Hespanha ${ }^{8}$, a disciplinarização peculiar típica das sociedades de Antigo Regime expressava-se em uma forma de "controle imaginado" que fazia com que os indivíduos imergissem em uma espécie de "controle de si mesmo" no sentido de dever, de obediência e de resignação. Cabe aqui destacarmos a função do Rei enquanto pai no sentido de fundamentar a interdição, de viabilizar o constrangimento e de assinalar o porquê, quando e como se poderia aplicar a punição. Era dele a última palavra, o que tornava a Justiça fortemente arbitrária e o colocava como centro ou o ápice do poder administrativo para onde todos os vetores deveriam convergir.

O Monarca constituía ainda uma forma de masculino ideal porque sua simples existência na organização sociocultural do Reino, e de suas conquistas aquém e além-mar, objetivava constranger os indivíduos a se relacionarem de acordo com um modelo ideal masculino. Este era expresso nos parâmetros comportamentais engendrados que ele e todos os outros deviam cumprir, assinalando um princípio paciente.

Entre os indivíduos o constrangimento se evidenciava mediante as tentativas de aproximação do modo de vida ideal da Corte, na sustentação do modus vivendi da nobreza. O modo de viver externava-se tanto através dos bens materiais, a exemplo do uso das indumentárias diferenciadas e de outros objetos de distinção e de satisfação, quanto por meio de hábitos e costumes, a exemplos dos ideais e das práticas de cavalaria medieval, ainda que com importantes alterações para o período moderno.

Dessa maneira, dado a ver como exemplo primordial, como um símbolo central, o Rei se portava de forma passiva, como uma representação. As aclamações dos Monarcas, os aparecimentos em público nas entradas régias sob o pálio cercado pelos homens mais ilustres do Reino, as demais cerimônias públicas que envolviam ele e seus representantes mais próximos (vice-reis, governadores, capitães, etc.) e a vida na Corte configuravam uma economia de gestos, de hábitos e de costumes que atuavam no reforço da representação masculina idealizada do Soberano e que os súditos deveriam observar e internalizar. Do Reino ${ }^{9}$ à América portuguesa essas questões eram prolongadas e se faziam sentir de várias formas, como nas cerimônias mundanas e religiosas, a exemplo da procissão de Corpus, Candeas, do Corpo de Deus, 
da Aclamação, recepção de autoridades, entre outras.

Dessa forma, a influência do Rei tanto tentava se aplicar de forma direta, real, ativa, como de maneira indireta, simbólica, passiva. Era estruturada e se estruturava por uma noção societária altamente desigual e engendrada que ultrapassava o Atlântico e buscava se reproduzir na América portuguesa. A figura do Monarca, como sugestão de varão ideal que servia de exemplo aos demais homens e que inventava, incitava, burlava e até mesmo modificava códigos socioculturais existentes pode ser pensada, inclusive, como uma forma de masculinidade hegemônica ${ }^{10}$ e uma dinâmica entre o protótipo masculino e a cultura engendrada que lhe era correspondente. ${ }^{11}$

Compreendemos que, principalmente no âmbito cultural, construíase e propagava-se a figura de um Soberano que necessitava reunir todos os atributos masculinos positivos. E isso deveria ser operado tanto por ele como por seus súditos mais próximos. Alguns reis, como Dom Duarte (1423-1481), se empenharam na construção de manuais comportamentais ${ }^{12}$, enquanto outros, como João de Barros, elaboraram panegíricos. ${ }^{13}$ A imagem do Monarca era uma idealização, enquanto os constrangimentos físicos e simbólicos operados pelo Rei sobre a sua Corte buscavam garantir a existência de uma conjuntura em que ele se projetava como um modelo engendrado, ao invocar o arquétipo gerador e ordenador do Rei.

Nesse sentido, importa assinalar o Rei como um protótipo masculino que buscava de maneira ativa (ações diretas) e passiva (simbolicamente) abalizar as ações dos súditos (nunca sem resistências ou distorções e traumas) apresentando-lhes e sendo apresentado conforme um ideal cultural generificado. Portanto, o Rei arquétipo, aqui indicado como masculino ideal, é semelhante àquele sugerido por Magalhães, através do Panegírico de João de Barros, um retrato perfeito que devia tocar e fazer sentido a qualquer indivíduo:

É o Rei arquétipo que se procura fixar e transmitir, sem traços singularizantes. O Rei que tem uma missão, que zela pelo bem dos súditos, que garante os equilíbrios da sociedade [dotado de todas as qualidades, como:] temperança, honestidade, humanidade, clemência, comedimento, bondade, amor, fortaleza, liberalidade, continência, verdade, vontade, firmeza, entendimento, constância, clareza, diligência, gravidade, lealdade, solicitude, prudência, discrição, magnanimidade $\mathrm{e}$ amor às letras ${ }^{14}$

Eis o arquétipo do Rei, pelo menos em expectativa, em sua plenitude: concentrando todas as virtudes e qualidades e apontando para características e uma posição singular inalcançável e de longa duração aos outros homens do Império português. Tanto em termos simbólicos e representacionais como por estar livre dos constrangimentos delineados pelos códigos de leis, o Rei 
buscava ser observado enquanto uma imagem masculina absoluta, incorporada consciente e inconscientemente pelos demais sujeitos.

Essa representação engendrada se apresentava como uma peça basilar na construção dos aparelhos psíquicos dos indivíduos, na constituição de suas relações de gênero, no entendimento que tinham do que era ser homem e do que era ser mulher e, portanto, na elaboração dos sistemas de entendimento, de percepção, de ação e de classificação no mundo em que viviam.

Diante da impossibilidade da quase totalidade dos homens se tornarem monarcas, tentava-se canalizar os seus anseios, desejos e vontades através de uma cultura masculinizante, onde lhes eram apresentadas possibilidades como as posições de sujeito vacantes, cujas ocupações deveriam passar pelo crivo do rei. Denominamos essa cultura expressa nos hábitos, nos costumes, nas práticas, nas leis, e em vários outros níveis, de "ideal de masculinidade" pelo fato de a correspondência régia obtida e expressa dentro de uma economia de mercês primar pelo reconhecimento e pela premiação de ações tidas como de caráter eminentemente masculino e, portanto, esperadas dos homens, pois enaltecedoras das ações que o Soberano valorizava enquanto próprias deles.

Nesse sentido, a introjeção de valores, de representações e de formas de pensar e de agir que se encontram registradas em ampla e diversa documentação oficial, desde a Vila mais afastada na Ásia até os domínios da América portuguesa, cuja premissa de fazer algo em nome D'El-Rey era a mais comum, assinalavam a possibilidade de continuidade de um tipo de relação constituída com o centro do poder régio. Nessa relação o Monarca tinha ocupação e função primordiais.

No plano ideal, o confronto de si mesmo com o masculino perfeito ao mesmo tempo em que deveria fazer com que os homens vissem as suas limitações indicava uma tentativa de incucar-lhes imperativos morais mais amplos. A expectativa da derrota do indivíduo previamente anunciada na comparação com a imagem régia era compensada por uma posição que o sujeito poderia ocupar na escala sociocultural. Era com essa ansiedade que ele tinha que se defrontar e não com o desejo de ocupar o lugar do Monarca. Enquanto o Soberano era dado a ver como ápice das virtudes, restava aos demais a tentativa de aproximação pela fidelidade e pela imitação. Eram essas as buscas de Diogo Botelho e muitos outros que se lançaram na aventura de colonização do Brasil.

As aspirações do Soberano eram projetadas sobre as dos súditos que deviam entendê-las como as suas próprias vontades. O ideal de masculinidade funcionava ou deveria funcionar, pelo menos em expectativa, como uma espécie de regulador das relações de gênero estabelecidas entre os indivíduos, que tinha como um dos princípios fundamentais a fidelidade e que assumia o Rei como centralidade.

Assim, no Estado português dos séculos XVI, XVII e XVIII os 
indivíduos se organizavam com base em um princípio andrógeno. O modo de observar o mundo (constituição de uma sociedade arraigada no arquétipo do Rei em suas funções fecundante e ordenadora - viril, portanto), a classificação hierárquica vigente (do moço ao fidalgo cavaleiro, isto é, do menos homem ao mais homem), os investimentos em objetos materiais fálicos na atividade cotidiana dos súditos (espadas, lanças, bestas, etc.), a ideia de um mundo delineado por um sistema de gênero altamente desigual e baseado no sexo único (subordinação das mulheres), entre outros aspectos, fomentavam a existência daquilo que Pierre Bourdieu ${ }^{15}$ denominou para outra comunidade mediterrânea de "inconsciente androcêntrico". Em Portugal, esse aspecto parece ter possuído não apenas correlato, mas uma longa duração e uma ampla circulação ao atuar nas representações, nas classificações e nas instituições sociais.

Os ideais da cavalaria, os títulos das diferentes Ordens Militares (que também tinham o Rei como Mestre e administrador perpétuo), as mercês régias, os brasões das famílias, a dinâmica das Casas, os livros e as memórias oficiais, entre várias outros, eram formas de internalização, de compensação, de satisfação, de manutenção e de circulação dos aspectos culturais engendrados no Império português. Colocavam em evidência o modo de funcionamento no plano simbólico imperial do qual eram parte estruturante e estruturada.

O convite, ou melhor, a coação para que os sujeitos vivessem naquela sociedade moderna era acompanhada pela internalização de uma cultura engendrada, "indispensável e sufocante ao mesmo tempo"16 por estar baseada, como em toda tentativa civilizadora, no bloqueio e na condenação de determinadas ações e na valorização e incentivo de outros atos e comportamentos:

É um homem assediado por necessidades inconscientes, com sua incurável ambivalência, seus amores e ódios primitivos e apaixonados, mal contido por coerções externas e sentimentos de culpa internos. As instituições sociais são muitas coisas para Freud, mas são sobretudo barreiras contra o assassinato, o estupro e o incesto. ${ }^{17}$

Ao partirmos da ideia de que as personalidades individuais (aparelhos psíquicos) dos portugueses eram formadas e estavam sob pressão incisiva de forças exteriores, assinalamos que os inconscientes individuais também eram formados pelos inconscientes sociais, ou melhor, social e historicamente constituídos. Todavia, como lembra António Manuel Hespanha "as relações entre privados, antes de serem reguladas pela vontade ou pelo direito estrito, eram-no pela natureza". ${ }^{18}$ Provavelmente aí residisse o principal desafio dos monarcas quanto às suas pretensões de enquadramento dos súditos e de estabelecimento de um poder absoluto sobre as relações de gênero, os comportamentos e os desejos sempre imprevisíveis e incontroláveis dos 
sujeitos. Mas antes de abordarmos esses aspectos, vejamos algumas das formas de enquadramento e o que elas tentavam delinear.

\section{As leis e a tentativa de conformar das masculinidades}

A lei, como uma intervenção direta do Rei na vida dos súditos, era um conjunto de dispositivos pelo qual o Soberano tentava ordenar os comportamentos, interditando determinadas ações, enaltecendo outras e orientando, inclusive, como deveriam ser utilizados os corpos ao assinalar de que maneira deveriam se dar as relações. O que as três Ordenações régias em Portugal nos sugerem é que havia uma tentativa de sobreposição dos interesses do Rei aos aspectos subjetivos de cada um dos indivíduos ou, dito de outra maneira, do masculino ideal sobre as outras formas de masculinidades, mediante uma idealização, isto é, a construção, a propagação e a introjeção de valores gerais: um ideal de masculinidade.

Dentre os cinco livros que compunham as Ordenações Filipinas são particularmente interessantes as disposições do Livro V que dispunha sobre a matéria penal. ${ }^{19}$ Dispostos em 143 títulos, ali se encontravam reunidos a caracterização e o tratamento de crimes diversos bem como suas correspondentes punições, segundo, claro, a condição social do infrator, garantindo a hierarquização e a manutenção da dissimetria entre os súditos, ao qualificar os homens como mais e menos importantes:

TÍTULO CXXXVIII - Das pessoas que são escusas de haver pena vil - Para que se saiba, quais devem ser relevados de haver pena de açoites, ou degredo com baraço e pregão, por razão de privilégios ou linhagem, mandamos que não sejam executadas as tais penas em os Escudeiros dos Prelados, e dos Fidalgos [...], nem em moços da Estribeira [...], nem em Pagens [...], nem em Juízes, e Vereadores, ou seus filhos, nem nos Procuradores das Vilas, ou Concelhos, nem em Mestres, e Pilotos de Navios [...], nem as pessoas que provarem, que costumam sempre ter cavalo [...], posto que peões, ou filhos de peões sejam, nem nos Mercadores que tratarem com cabedal de cem mil réis, e daí para cima. ${ }^{20}$

As "penas vis" eram formadas por punições altamente degradantes para os culpados, como o envio para as galés, os açoites, as marcas impingidas nas costas, o corte de membros do corpo, o baraço (uma espécie de cadeia ou corda que se colocava no pescoço) e a forca. Aos homens de qualidade eram propostas como penas alternativas o degredo para a África ou para o Brasil.

Contudo, existiam infrações que a lei mandava punir sem qualquer 
diferenciação. Apresentados no parágrafo segundo do mesmo título, o primeiro deles era o crime de Lesa Majestade, ratificando nossa proposição quanto à importância da fidelidade no constructo masculinizante, seguido pelos de sodomia, de falsidade (testemunho falso, moeda falsa), furto, feitiçaria e alcovitaria. A todos esses crimes as penas deveriam ser executadas sem qualquer diferenciação. Deveriam...

A preocupação em torno de três desses dolos era uma constante que se prolongava para os limites de além-mar, mostrando a atenção régia quanto às infrações nocivas ao seu poder. Referimo-nos aos crimes de Lesa Majestade, sodomia e falsidade, acrescidos da heresia. Aos governadores, capitães, ouvidores e donatários das capitanias das partes do Brasil, o Rei conferia alçada legal para punir indiferentemente os criminosos que enveredassem em tais práticas, ainda que estes possuíssem qualidade de sangue:

[...] e nos casos crimes hei por bem que o dito capitão e governador e seu ouvidor tenham jurisdição e alçada de morte natural inclusive em escravos e gentios e assim mesmo em peões cristãos, homens livres, em todos casos assim para absolver como para condenar sem haver apelação nem agravo, e nas pessoas de maior qualidade terão alçada de dez anos de degredo até cem cruzados de pena sem apelação nem agravo, e porém, nestes casos seguintes que são quatro: heresia, quando o herético lhe for entregue pelo eclesiástico, traição, sodomia e moeda falsa, terão alçada em toda pessoa de qualquer qualidade que seja para condenar os culpados à morte e dar suas sentenças à execução sem apelação nem agravo [...]. ${ }^{21}$ (grifo nosso).

Fragmento da Carta de Doação da Capitania do Espírito Santo concedida a Manuel Garcia Pimentel em 1675, o trecho acima indica claramente a tensão em torno dos crimes específicos que deveriam ser estritamente observados pelos representantes do Monarca na América portuguesa. A heresia, a traição, a sodomia e a moeda falsa eram, inclusive, assuntos particularizados no livro das Ordenações, com punições variadas, mas que tinham uma ligação estreita pela possibilidade de levarem ao confisco dos bens, ao castigo físico e à morte dos seus praticantes:

\begin{tabular}{|l|c|c|c|c|c|c|}
\hline \multicolumn{7}{|c|}{ TABELA 1 - Crimes e punicões } \\
\hline $\begin{array}{c}\text { Refe- } \\
\text { rência }\end{array}$ & Identificação & $\begin{array}{c}\text { Confisco } \\
\text { (bens e } \\
\text { ofícios) }\end{array}$ & Degredo & $\begin{array}{c}\text { Castigo } \\
\text { Físico }\end{array}$ & Morte & $\begin{array}{c}\text { Descen- } \\
\text { dência }\end{array}$ \\
\hline $\begin{array}{l}\text { Liv. 5; } \\
\text { Tít. I }\end{array}$ & $\begin{array}{c}\text { Dos Hereges e } \\
\text { Apostatas }\end{array}$ & $\mathrm{x}$ & & $\mathrm{x}$ & $\mathrm{x}$ & \\
\hline $\begin{array}{l}\text { Liv. 5; } \\
\text { Tít. VI }\end{array}$ & Lesa Majestade & $\mathrm{x}$ & & $\mathrm{x}$ & $\mathrm{x}$ & $\mathrm{x}$ \\
\hline
\end{tabular}




\begin{tabular}{|l|c|c|c|c|c|c|}
\hline $\begin{array}{l}\text { Liv. } \\
\text { 5; Tít. } \\
\text { XII }\end{array}$ & $\begin{array}{c}\text { Dos que fazem } \\
\text { moeda falsa, ou } \\
\text { a despendem, } \\
\text { e dos que } \\
\text { cerceiam a } \\
\text { verdadeira, ou a } \\
\text { desfazem. }\end{array}$ & $\mathrm{x}$ & $\mathrm{x}$ & $\mathrm{x}$ & & \\
\hline $\begin{array}{l}\text { Liv. } \\
\text { 5; Tít. } \\
\text { XIII }\end{array}$ & $\begin{array}{c}\text { cometem quecado } \\
\text { de sodomia, } \\
\text { com alimárias }\end{array}$ & $\mathrm{x}$ & $\mathrm{x}$ & $\mathrm{x}$ & $\mathrm{x}$ & $\mathrm{x}$ \\
\hline
\end{tabular}

A abominação de dois deles era tão forte que a punição se ampliava e alcançava, inclusive, os descendentes afetados pelos atos dos pais. Referimonos à traição e à sodomia. Em uma sociedade de "casas" onde a traição era crime comparado à lepra, se o patriarca fosse identificado como traidor, além da morte cruel que lhe cabia, a sua memória deveria ser "danada" 22 e os seus filhos e netos homens seriam infamados, tornados inábeis e impossibilitados de receber bens materiais e outros elementos distintivos masculinizantes, tal como a honra de cavalaria. ${ }^{23}$

Essa, aliás, era a mesma lógica para o pecado nefando de sodomia explicitamente comparado ao crime de Lesa Majestade. Acrescida a possibilidade de degredo à de confisco e à de castigo físico, não apenas o corpo do praticante deveria ser queimado e feito "por fogo em pó". ${ }^{24}$ Igualmente à sua matéria corpórea, sua memória deveria inexistir, enquanto que os descendentes de duas gerações sofreriam as consequências desabonadoras da mácula dos atos de seus patriarcas.

A amplitude do significado da sodomia possuía ainda outras ressonâncias. Segundo Joaquim Ramos de Carvalho ${ }^{25}$ (2011), a sodomia e a homossexualidade constituíam comportamentos que implicavam que seus autores teriam deixado de acreditar nos princípios da fé católica o que, dessa maneira, aproximava-os da condição de herege e tornava-os passíveis de perseguição pela Inquisição, haja vista que cometia heresia "a pessoa que crê ou sustenta com tenacidade um sentimento declarado por errôneo, contra a Igreja" 26 .

Contudo, nem sempre as definições foram tão claras. ${ }^{27}$ Mais do que a possível associação entre sodomia e heresia, importa destacarmos a estreita e expressa ligação existente entre a traição e a sodomia em um movimento delineador de um ideal de masculinidade. É nesse sentido que podemos entender como a deslealdade ao Monarca e a sodomia, passíveis de serem cometidos tanto pelos súditos "machos" como pelas "fêmeas", tinham um julgamento conforme o gênero.

Para os eventos em que eram as mulheres evidenciadas como traidoras, o parágrafo terceiro do Título I das Ordenações Filipinas afirmava que a pena e a infâmia não passaria da primeira geração (filhos diretos), 
diferentemente dos homens que tinham a infâmia propalada até a geração dos netos. Já em relação à sodomia feminina (sodomia foeminarum), esta acabou por ser descriminalizada em Portugal no ano de 1646, embora a cópula anal entre o homem e a mulher considerada "sodomia imperfeita" continuasse a ser perseguida pelos padres do Santo Ofício.

A definição de "sodomia perfeita" elaborada na teologia por São Tomás de Aquino era tida como um ato sexual específico onde havia a penetração no "vaso traseiro" com o derramamento de semente dentro do mesmo, ou seja, uma ação contrária à finalidade da prática sexual voltada exclusivamente para a reprodução. Assim, para que existisse sodomia de fato havia a necessidade material do pênis, isto é, do homem.

A lealdade ao Rei devia ser seguida à risca não apenas para evitar o crime de traição. A fidelidade recaía sobre o corpo a ser utilizado conforme os parâmetros régios. Daí inferirmos a aproximação e a similitude dessas duas infrações por sugerirem um delineamento do ideal de masculinidade que indicava o perigo da figura do traidor em seu ápice, tanto em termos políticos, econômicos, militares e religiosos, como em torno das práticas sexuais, haja vista as designações e observações do corpo e das possíveis relações prescritas.

As invenções legislativas de enquadramento e punição das práticas sexuais imperfeitas não eram exclusividade do Código Filipino. As Ordenações Afonsinas e Manuelinas já haviam feito referência aos sodomitas. Aliás, a rigidez com que esses códigos de leis trataram as práticas sexuais parecia estar imersa em um movimento mais amplo de menor aceitabilidade iniciado entre fins do século XIII e início do XIV, quando "as sociedades europeias parecem ter se inclinado à restrição, à contração, à proteção, à limitação e à exclusão [marcadas] por ideias profundamente modificadas no público acerca da gravidade dos atos homossexuais". ${ }^{28}$

Juridicamente menos sofisticada, a citação do crime de sodomia no Código Afonsino focava na torpeza do pecado pela ofensa geral que fazia a Deus e às demais pessoas. Assinalando os castigos divinos empreendidos outrora sobre os sodomitas, a lei não definia minuciosamente tal prática, embora focasse a necessidade de punição severa e extensiva:

Sobre todos os pecados bem parece ser mais torpe, sujo, e desonesto o pecado da Sodomia, e não é achado outro tão avorrecido (sic) ante DEUS, e o mundo, como ele; porque não tão somente por ele é feita ofensa ao Criador da naturaleza, que é Deus, mais ainda se pode dizes, que toda natura criada, assim celestial como humanal, é grandemente ofendida. E segundo fizeram os naturais, somente falando os homens em ele sem outro algum auto, tão grande é o seu favorecimento, que o ar o não pode sofrer, mais naturalmente é corrompido, e perde sua natural virtude. 
E ainda se lê, que por este pecado lançou Deus o dilúvio sobre a terra, quando mandou a Noé fazer uma Arca, em que escapasse ele, e toda sua geração, por que reformou o mundo de novo; e por este pecado soverteu as Cidades de Sodoma, e Gomorra, que foram das notáveis, que aquela razão havia no mundo; e por este pecado foi destruída a Ordem do Templo por toda a Cristandade em um dia. E porque segundo a qualidade do pecado, assim deve gravemente ser punido; porém Mandamos, e pomos por Lei geral, que todo homem, que tal pecado fizer, por qualquer guisa que se possa, seja queimado, e feito por fogo em pó, por tal que já nunca de seu corpo, e sepultura possa ser ouvida memória. ${ }^{29}$

Diferentemente e seguindo rigorosa linha punitiva com expectativa de proliferar o medo, as Ordenações Manuelinas apresentaram o crime de sodomia de forma mais elaborada, mas ainda assim não trouxeram uma definição detalhada do mesmo. Ali, pela primeira vez, a sodomia foi associada, mediante a sua penalidade, ao terrível crime de Lesa Majestade acrescida da possibilidade de confisco de bens em prol da Coroa. Ademais, foi incluída uma nova personagem: a que tinha conhecimento das "somitigarias" e que, caso não fizesse denúncia, poderia ser punida de maneira semelhante ao sodomita. ${ }^{30}$

De forma continuada, os três códigos de leis assinalavam aqueles(as) que estariam fora das relações ideais por cometerem o abominável pecado de sodomia, ou simplesmente pecado nefando, definido assim por ir contra a natureza, não podendo ser dito e por ser "indigno de definição da sua torpeza" . ${ }^{31}$ Todos esses eram (des)qualificados como "sodomitas" ou "fanchonos" e aproximados de outros práticas sexuais e sensuais tidas como torpes, como a alimária e a molície.

Albergado como invenção do Código Manuelino, a criação legal do sujeito que mantinha relação sexual com animais (alimária) encontrou repercussão nas Ordenações Filipinas..$^{32}$ Duramente punidos, os criminosos e pecadores, bem como os animais usados nesses atos, deveriam ser queimados como os sodomitas por desviarem o sexo da sua finalidade reprodutora e por irem contra a sua natureza. A diferença entre o sodomita e aquele que incorria em alimária no âmbito punitivo consistia unicamente na não extensão dos castigos às gerações descendentes. ${ }^{33}$

$\mathrm{O}$ "pecado de molície", também referendado posteriormente como "onanismo", diferenciava-se pela inexistência de penetração. Eram os "tocamentos desonestos". ${ }^{34}$ Nessa infração estavam inseridas várias práticas sexuais consideradas torpes como a masturbação individual ou a dois, a felação, a anilíngua, entre outras. Embora não possuísse correspondência com os códigos anteriores, o pecado de molície foi amplamente tratado por Filipe II, tanto nas Ordenações como em suas Leis Extravagantes, ao retomar a lei de 1571 feita 
por D. Sebastião e a lei de 1597 de Filipe I, no sentido de dirimir possíveis confusões de definição e de castigo:

Hei por bem, e mando que todas as pessoas, de qualquer qualidade e condição que forem, que por si, ou por outra pessoa, do mesmo ou diferente sexo, ou por qualquer outro modo, cometerem o pecado de molície, sejam presas, e pela primeira vez, sendo peões, com baraço e pregão sejam publicamente açoitados, e degradados sete anos para as galés; e sendo de maior qualidade, em que não caiba pena vil, com pregão em audiência sejam degradados por sete anos para o Reino de Angola sem remissão; e sendo segunda vez compreendidos por prova legítima no mesmo pecado, se lhes poderá acrescentas a dita pena, até morte natural inclusive, segundo o modo da reincidência, e perseverança, com que o cometerem. ${ }^{35}$

Desvelando a maior atenção régia para com as relações sexuais desonestas, essa lei de 1607 acrescentava a possibilidade da pena de morte além de avançar em outras peculiaridades em relação às determinações do Código Filipino. Assim, por exemplo, os indivíduos nobres e moradores da casa régia ficavam sujeitos não apenas a perda da nobreza e de serem apagados das listas dos livros de residência do Rei. Podiam receber pena de degredo para as galés ou mesmo condenação à morte. $\mathrm{O}$ controle e a penalização, quase sempre exemplar, buscavam perscrutar os âmbitos mais íntimos da vida dos indivíduos de todos os segmentos sociais.

Objeto de ressonância das práticas da Igreja em muitos e variados pontos, como a ação fiscalizadora, o estímulo à delação com premiação ou perdão e a punição proporcional ao delito e à condição social do indivíduo, as Ordenações Filipinas traçavam, portanto, um enquadramento moral e corporal quanto às práticas comportamentais nocivas e salutares.

A sodomia indicava uma depreciação engendrada do outro que a teria praticado, principalmente se fosse paciente na ação. Nas denúncias coletadas por Heitor Furtado de Mendonça na Primeira Visitação do Santo Ofício ao Brasil (1591-1595) foram várias as acusações de sodomia, tanto na Bahia, onde a comitiva inquisitorial permaneceu até 1593, como em Pernambuco, para onde migrou posteriormente. ${ }^{36}$

Dentre eles, é interessante a denúncia feita por João da Rocha Vicente, um cristão-velho, casado, de Viana da Foz que contava com 48 anos e morava em Pirajá. O denunciado, Martim Carvalho, foi um homem que obteve destaque no avanço feito pelas terras brasílicas como capitão da bandeira de 1576, em Porto Seguro. Atuou diretamente na conquista da capitania da Paraíba dando, segundo o denunciante, um aspecto singular à penetração do sertão: 
[João da Rocha Vicente] ouviu ser fama pública geralmente em Porto Seguro que o capitão Martim Carvalho cometia o nefando com um mancebo por nome Baltazar Vieira, já defunto, 'e que neste pecado pecavam na jornada do sertão... conforme disseram muitas pessoas das muitas que iam naquela jornada, o qual Martim Carvalho ouviu dizer que era mandado ao Reino por este caso [em 1593]. ${ }^{37}$

A denúncia revestia-se de singularidade pela experiência de vida e pela qualificação do acusado. Martim Carvalho, casado com Dona Luíza Dória, era uma "pessoa nobre", militar e cristão-velho que tinha exercido diferentes cargos de confiança do Monarca, tais como a Tesouraria das Rendas na Bahia, a Provedoria da Fazenda da Armada de Diego de Flores Valdes e a Provedoria Mor da Fazenda em Pernambuco. Dito de outra forma: possuía interlocução direta com Felipe I e era responsável pela fiscalização, controle, denúncia e punição daqueles que agiam contra os interesses da Coroa, fundamentalmente no que tocava à arrecadação dos direitos da Fazenda.

Amplamente citado pelos cronistas de sua época, tais como o padre jesuíta Cristóvão de Gouvêa (Sumário das Armadas - 1584), Gabriel Soares de Sousa (Tratado Descritivo do Brasil em 1587) e Pero Magalhães Gândavo (Tratado das Terras de Santa Cruz - 1576), Martim Carvalho se envolveu em contendas e nutriu o ódio de muitos inimigos em virtude da sua postura firme no tratamento das questões relativas aos bens da Coroa. A sua atuação, por exemplo, teria gerado uma celeuma com o ouvidor geral Martim Leitão pela coibição que ele fez diante dos abusos de dois oficiais de Pernambuco, amigos do ouvidor. ${ }^{38}$

Assim, antes da visitação do Santo Ofício, de todas as formas e pelas ações desprendidas e registradas, Martim Carvalho era investido dos principais elementos masculinizantes enaltecidos pelo Monarca e pelos seus pares, tanto que ascendia como representante régio em um dos principais cargos da América portuguesa ao cuidar e proteger o dinheiro do Rei. No quadro do ideal de masculinidade previamente traçado, ele possuía uma posição de sujeito amplamente reconhecida e respeitada, estando em constante e direto diálogo com o masculino ideal.

Diante das desavenças celebradas na época em que foi provedor não há como sabermos se a denúncia era real ou fictícia fazendo parte de uma possível tentativa de desabonar Carvalho. ${ }^{39}$ Contudo, isso aqui importa pouco. $\mathrm{O}$ fato é que a delação do pecado nefando atuava de forma altamente depreciadora em relação a ele, com a possibilidade de macular não apenas a sua memória como também a sua imagem masculina, além de pôr em risco, segundo as Ordenações, a sua própria vida. O efeito de verdade da ação e não a verdade do fato propriamente dita poderia gerar consequências desastrosas.

Mais que isso, a denúncia mostrava como a sodomia indicada por 
João da Rocha e por várias outras testemunhas que se apresentaram diante do Visitador surgia como uma possível prática e assunto comum, cotidiano e ordinário nas conquistas das capitanias do Norte ou mesmo como uma prática presente nas vivências dos conquistadores. Eles sabiam como identificá-la, caracterizá-la, defini-la e, não resta dúvidas, realizá-la. A penetração espacial do sertão era acompanhada pelo conhecimento e por outros tipos de penetrações caracterizadas nos códigos de leis como depreciadoras, mas nem por isso pouco praticadas e menos prazerosas para os seus praticantes. Distantes dos discursos régios, as masculinidades se encontravam testadas e alteradas na América portuguesa e, acreditamos, em muitas outras partes do Império. As experiências de Diogo Botelho ajudam a nuançar essa proposição.

\section{Uma casa às avessas.}

No início do século XVII e com as atenções voltadas para a América portuguesa surgia como modelo de "homem idôneo", isto é, bem merecido e com habilidades nas artes de governar e de guerrear, um sujeito que atendia pelo nome de Diogo Botelho. Em seu conjunto de dados pessoais constavam feitos nada tímidos ou modestos: combateu ao lado do rei Dom Sebastião, em África, na Batalha de Alcácer-Quibir. Mais tarde, entre os integrantes preferidos do Conselho de Felipe II era ele indicado para o cargo de Governador Geral das "partes do Brasil". ${ }^{40}$

A representação de Botelho feita pelos seus pares na América portuguesa era consoante à sua posição e ofício, pois identificado com os princípios ordenador, controlador, incorruptível, com expressa atenção à aplicação da lei e ao princípio da Justiça direcionado a todos, além de se apresentar como exímio regulador das finanças e defensor aguerrido das terras brasílicas contra os estrangeiros. Tudo isso influenciava os homens nobres da terra e da governança a afirmarem "o amor que lhe tem". ${ }^{41}$

Esses homens falavam com a propriedade da proximidade e do diálogo constante, argumentando que sabiam "por assistir na casa do dito governador". ${ }^{42}$ No exercício da governança, as reuniões do Conselho aconteciam na maior parte das vezes nas pousadas do governador geral, tanto em Olinda como em Salvador. Ali, portanto, reuniam-se ouvidores, provedores, capitães, sargentos, entre outros oficiais do alto escalão do Império no Brasil.

As relações que o governador geral mantinha com a sua casa e em sua casa eram amplamente divulgada por outros varões, tanto que, ainda em 1607, era lembrada em certidões passadas pelos juízes e vereadores da Câmara da cidade de Salvador:

Teve sempre a porta aberta, assim de dia como de noite, sem porteiro, para a qualquer hora ouvir as partes retirando-se 
de todos os impedimentos, porquanto nunca engana, nem ia comer fora, nem a outras partes mais que os mosteiros e lugares de guerra a defendê-los e mandá-los fortificar, conservando em tudo a autoridade do seu cargo. ${ }^{43}$

A dita recepção indiscriminada e sem restrição de horário na casa se tornou amplamente conhecida junto com a afabilidade com que escutava e tratava os súditos do rei, pois "conserva-se no seu lugar de governador, assim em particular como em público". ${ }^{44}$ Não havia dúvidas quanto à intensidade com que os indivíduos frequentavam as pousadas de Diogo Botelho, em virtude do modo que ele lidava com aquele espaço. Contudo, existiam outras questões mais delicadas que não passavam pela incumbência da governança e que sinalizavam outras formas de se relacionar com a casa e na casa.

No movimento expresso nas entradas, permanências e saídas das pousadas do governador geral, aconteceram não apenas troca de missivas oficiais, apertos de mãos e conselhos deliberativos. Ali, algumas das permutas de mensagens foram convertidas em trocas de fluídos corporais; outros toques formais e superficiais foram substituídos por contatos mais profundos e íntimos; e a intensidade das reuniões matinais passou a ser acompanhada por orgias homossexuais que, dependendo da ocasião, poderiam acontecer tanto durante o dia quanto à noite. $\mathrm{O}$ corpo do homem, registro de sofrimento na busca por mercês, como registravam os soldados e súditos do Monarca, assumia outra valorização nesse contexto: penetrava e era penetrado pela "natura" do outro. ${ }^{45}$

Quem deu notícia dessas variações nos aposentos oficiais do governador geral foi Fernão Rodrigues de Sousa, em 12 de setembro de 1618, quando o senhor inquisidor Marcos Teixeira promoveu a Segunda Visitação do Santo Ofício ao Brasil (1618-1620). ${ }^{46}$ Assim como os demais indivíduos arrolados acima, Fernão possuía livre acesso à casa de Diogo Botelho, mas com o diferencial de possuir idade de onze anos e de servir como pajem do governador pelos idos de 1604, o que the possibilitou vivenciar muitos contatos proibidos e práticas tidas como nefandas pelas Ordenações Filipinas.

Fernão Rodrigues, quando se apresentou ao Santo Ofício, afirmou ser um cristão velho, natural de Vila Galega no Reino, casado, que morava na Freguesia de Nossa Senhora do Socorro e com idade aproximada de 25 anos. Possuía insígnias que o diferenciavam dos homens comuns, pois era um cavaleiro fidalgo com registro nos livros de Sua Majestade de ofício régio. Entretanto, ali, diante do inquisidor e dos padres Domingos Monteiro e Manoel Sanches, o Fernão Rodrigues que surgia era outro, incitado pelo medo da condenação e desvelado por suas memórias que sinalizavam experiências sexuais tidas como destoantes e que envolviam diretamente o governador geral, aquele que mais deveria espelhar a imagem de uma masculinidade idealizada do Rei no Estado do Brasil.

O confidente apresentava um conjunto de lembranças que sinalizavam 
uma relação íntima, de longa duração e de amplo alcance espacial para alémmar. Segundo Rodrigues, o principal representante varão do Soberano nas partes do Brasil tratava-lhe com muitos mimos e favores, intencionando levá-lo para a cama e dormir carnalmente com ele, o que aconteceu pela primeira vez por volta de 1604, perdurando por quase uma década, ou seja, mesmo depois que Botelho voltou para Lisboa, em uma de suas casas, perto do Chafariz dos Arroios.

A primeira relação sexual entre Fernão Rodrigues e Botelho ocorreu na sede do Governo Geral, espaço onde deliberavam os súditos do Monarca e principal ponto de conexão dos colonizadores e conquistadores com o poder régio central. A mesma casa, que ficou conhecida por suas portas abertas dia e noite e na qual o governador deveria representar bem a autoridade de seu cargo, entrava para os registros inquisitoriais como um espaço de prazeres proibidos e contrários à natureza. Afinal, um espaço de homens deveria reunir práticas efetuadas pelos homens e próprias deles.

A força física e o esforço, tão valorados como atributos dos varões nas atividades de conquista também apareciam nessa ocasião, mas delineavam uma imagem diferente daquela do cavaleiro combatente que foi "Capitão na Batalha de Alcácer [...] na África onde levou dois navios a sua custa e a se achar na dita batalha com cinco de cavalo e doze arcabuzeiros". ${ }^{47} \mathrm{O}$ esforço de Botelho direcionado a Fernão estava expresso nos presentes dados para obter recompensas sexuais. Não sendo feliz em sua estratégia de sedução, conseguiu penetrar o traseiro do confidente "por força e contra a vontade dele, [o qual] com medo de o dito cúmplice o matar, não se atreveu a gritar". ${ }^{48}$

Inicialmente, a força foi substituída pela sedução (expressa no induzimento e no pedido) e pela provocação como medidas utilizadas por Diogo Botelho para dormir carnalmente com Fernão Rodrigues por quase uma década, o que, nas contas do denunciante, aconteceu entre quinze e vinte vezes, mas que, na prática, poderiam ter sido muito mais. As somitigarias tinham espaço tanto de dia como de noite, quase sempre após as refeições de jantar e ceia, momentos em que o governador geral deitava na cama e chamava o denunciante e outros homens, dando início a atividades sexuais em grupo:

[...] e que de noite e de dia aconteceram os casos de que se acusava; de dia, quando havia ocasião; e de noite, quando o dito Diogo Botelho chamava a ele confitente para a sua cama, e a algum dos outros cúmplices, e na sua cama estando o dito Diogo Botelho também lançado na cama, cometiam todos três o dito pecado nefando de sodomia; e que de dia pela maior parte era depois do jantar; e de noite, depois da ceia quando estavam recolhidos para dormir. ${ }^{49}$ 
Em número de seis, os afetos do governador geral foram citados por Fernão Rodrigues um a um. Eram eles Diogo da Silva (natural de Alcochete no Reino, com idade de vinte e cinco anos, solteiro, almoxarife da cidade), Antonio Galvão (natural de Salvador, com quatorze anos), João de tal (guarda), Agostinho Ferreira (solteiro, filho de tabelião), Nicolau Soares (casado, capitão da guarda, com aproximadamente 26 anos) e Anrique (flamengo, casado e com vinte e cinco anos). ${ }^{50}$

Exceto pelo último, todos foram citados como criados de Diogo Botelho, o qual, em 1604, deveria possuir experientes quarenta e sete anos contra os onze de Fernão Rodrigues. Na casa, ou melhor, na cama com Botelho, eram esses corpos que se abraçavam, se entrecruzavam e se penetravam mutuamente, haja vista que "o dito Diogo Botelho [cometeu] o pecado nefando de sodomia com os sobreditos, umas vezes paciente, outras agente". ${ }^{51}$

Desse testemunho, inclusive, não seria absurdo supor que a economia de mercês também girasse em torno de trocas e favores sexuais entre os representantes do Rei. Possuindo o direito de passar certidões e de comprovar as façanhas dos súditos, Diogo Botelho se apresentava como importante interlocutor do Soberano. Assim, a tarefa de agradar ao governador poderia assumir múltiplas facetas, trocas e conexões, inclusive, carnais.

Rechaçada pelos inquisidores, a torpeza das ações de Diogo Botelho não parava no ato de cometer o pecado em si. O governador geral tinha outros desejos e vontades diferentes que, na contemporaneidade, seriam denominados e enquadrados patologicamente pela psiquiatria como voyeurismo, isto é, o prazer sexual obtido pela observação de cenas íntimas e eróticas. ${ }^{52}$ Muito provavelmente a invenção do pervertido de hoje tenha relação com a invenção dos fanchonos, somítigos e sodomitas de outrora. O discurso específico sobre a prática de ver o outro em ato libidinoso ainda não tinha sido inventado no tempo de Botelho.

Fernão Rodrigues assinalou várias vezes em sua denúncia como era constrangido pelo governador geral, para que realizasse o ato sexual com um terceiro em presença daquele. Para tanto, Botelho pedia, instigava e mandava, a fim de "se provocar e incitar". ${ }^{53} \mathrm{O}$ confidente funcionava como uma espécie de serviçal sexual, que deveria excitar o seu superior fazendo sexo com outros homens. Na lista enunciada pelo próprio depoente, chegava-se a enumerar a quantidade de vezes ou o tempo decorrido em tais práticas: com Anrique e Agostinho Ferreira, três ou quatro vezes; com Diogo da Silva, oito ou dez vezes; com João de tal, entre quinze e vinte repetições; e com Antonio Galvão, uma longa temporada de oito anos.

Mais uma vez, os locais para tais atos de incitação e de observação eram quase sempre as pousadas de Diogo Botelho, onde a intensidade e a recorrência das orgias despertavam a curiosidade dos demais serviçais da casa e de outras pessoas de fora: 
Respondeu que não sabia de mais testemunhas que as que tem dito que fossem de vista que ele confidente soubesse; e que era verdade que os criados de casa davam a entender que o suspeitavam, e havia entre eles escândalo disso; e que pelos muitos mimos e favores que o dito Diogo Botelho fazia a ele confidente, não faltaria gente de fora que o suspeitasse, maiormente tendo o dito Diogo Botelho fama disso. ${ }^{54}$

Na tentativa de fuga dos olhares sorrateiros, inclusive, surgiam outros locais para o exercício das práticas condenadas, a exemplo de onde vivia Nicolau Soares:

que esta num engenho seu no Jaguaribe 14 ou 15 léguas desta cidade. E ele confidente o viu entrar e sair muitas vezes em camisa e ceroulas na câmera do dito Diogo Botelho depois da meia noite; e que disso suspeitava ser verdade o que o dito Diogo Botelho lhe tinha dito, e também por o dito Diogo Botelho ter pedido a ele confidente que cometesse o mesmo pecado nefando com o dito Nicolau Soares, que sabe por lhe o dito Diogo Botelho dizer que ele confidente o cometia com ele. ${ }^{55}$

Assim tanto nas pousadas de Diogo Botelho como em outros espaços, as experiências e ações dos homens não refletiam e cumpriam regularmente as orientações oriundas do Reino. A imagem do cavaleiro montado e vestido com o honroso hábito das ordens militares que alimentava o ideal de masculinidade no Império ultramarino era contrastada pelas imagens estimuladas pelo oitavo governador geral do Estado do Brasil, o qual se excitava em ver os seus subordinados se acariciando, se tocando e se penetrando mutuamente na busca de um prazer intenso e não prescrito nos corpus da lei. ${ }^{56}$

Os predicados masculinos apareciam alterados de sentido nas experiências constituídas pelos homens. A força para segurar o amante, o esforço e a estratégia para seduzi-lo, a fidelidade no trato com os segredos, a coragem para cometer atos condenados pelo Rei e pela Igreja, e o corpo acariciado em suas partes, como as cicatrizes e as barbas, continuavam como elementos fundamentais na constituição e identificação daqueles homens. A imagem final, entretanto, havia sido transmutada e não correspondia ao ideal masculino apregoado do centro régio.

E tendo em vista a quantidade de vezes que esses eventos aconteceram, a pluralidade de indivíduos envolvidos e o estado mental em que cada um se encontrava, sem nunca o confidente ter visto os cúmplices "fora de juízo, nem tomados do vinho [e tendo clareza] que o pecado nefando de sodomia de que se acusava era meter sua natura pela parte traseira do cúmplice, e derramar 
dentro em seu corpo a semente genital ou consentir fazer-lhe o cúmplice o mesmo", podemos inferir o quanto aqueles aspectos compunham outra forma identitária válida entre os cristãos velhos, homens casados, cavaleiros, capitães, governadores, ouvidores, provedores e muitos outros. Da segunda visitação do Santo Ofício, por exemplo, além dos indivíduos já citados, dezenas de outros foram identificados como sodomitas, conforme podemos ver na Tabela 2.

Aliás, as visitações ao longo dos séculos XVI, XVII e XVIII mostraram a existência de práticas de sodomia não apenas na Bahia, mas em Olinda, Paraíba e várias outras freguesias do Brasil, como também em Angola, nos Açores, na Ilha de São Miguel, de Madeira e em quase todo Império português. ${ }^{57}$ Espalhados pelo mundo do Império português, esses homens buscavam mercês régias testemunhando que cumpriam os aspectos assinalados pelo ideal de masculinidade, espelhando características masculinas.

Registravam isso em suas petições, certidões, autos, regimentos e em muitos outros documentos. No entanto, estratégica e deliberadamente, esqueciam de registrar outras formas e práticas feitas pelos homens, outros sentimentos e outros desejos, como o prazer no sexo anal que, embora proibidos pelos discursos hegemônicos, não deixavam de acontecer nos potentados do Império e nas sociedades Antigo Regime. ${ }^{58}$

Não há como sabermos se a acusação feita por Fernão Rodrigues de Sousa era verdadeira. Entre as diferentes contendas que o governador geral se envolveu, essa denúncia podia representar mais uma disputa política. Contudo, não encontramos quaisquer outras fontes que permitam aprofundar ou negar a questão. Tudo o que disséssemos a respeito seria mera especulação. Sabemos apenas que, após a saída do denunciante da sala em que foi inquirido, os padres se entreolharam dizendo "que lhes parecia que ele [Fernão] falava verdade e que se lhe havia de dar crédito" 59 , no que procederam à recepção e assinatura da denúncia junto ao Senhor Inquisidor.

Para os propósitos deste artigo, interessa-nos o pouco ou nenhum alcance de efeito de verdade que essa denúncia tenha gerado no contexto posterior ao governo de Botelho no Brasil. Como se esperava dos sodomitas, caso tivesse sido condenado, os bens do governador deveriam ter sido confiscados e reduzidos, mas isso não aconteceu. Pelo contrário, a sua casa foi engrandecida. Os reconhecimentos de Filipe II e Filipe III, conferidos às ações do filho de Diogo Botelho, foram de fundamental importância na confirmação de que sua memória não foi prejudicada.

Nuno Álvares Botelho, foi nomeado em 1617 como capitão mor da viagem à Índia, onde atuou no combate a diferentes inimigos, como os ingleses, os holandeses e os persas. Nesse espaço deu assistência direta ao Vice-rei D. João Coutinho, comandando várias embarcações nos constantes deslocamentos pelo Oceano Índico. Para o domínio da cidade de Málaca, por exemplo, combateu, aniquilou e incorporou o material bélico das tropas do 
Sultão de Achém, que contavam com mais de duzentas embarcações e quase vinte mil homens. ${ }^{60}$ Sobre o seu espírito aguerrido, o próprio Nuno Botelho fazia questão de expor em suas correspondências:

Faço saber aos generais de Inglaterra, e de Holanda, que, depois das batalhas que the dei em fevereiro passado, no mar de Ormuz, me aprestei em Mascate para os vir esperar nesta costa, como fiz nas paragens de Dabul e Chaul, que as suas naus costumam tomar de ordinário [...], os quis vir demandar para os desafiar à batalha [...]; e tendo os ditos generais mais naus das com que me acho, não poderão aparecer de soldados escusar-se deste desafio [...], com minha palavra jurada, pela vida de meu rei e senhor, de não abrigar com ele com mais naus das com que me sair, e se dentro de três dias seguintes [...], o não fizerem se entenderá claro que faltam no dito desafio, e que fica por eles, o que não espero [...]. E para que este desafio venha à notícia de todos mandei fixar este quartel nos lugares públicos da fortaleza e Cidade de Surrate. ${ }^{61}$

Esse homem não foi impedido de receber mercês, apesar das possíveis ações nefandas cometidas por seu pai, o que põe em questão, mais uma vez, o baixo alcance da denúncia de Fernão Rodrigues. Nuno Botelho, inclusive, no momento em que escreveu o texto acima, já se anunciava como comendador das comendas de Santa Maria de Mirandela, de São Julião de Zurara, e de S. Miguel de São Riade da Ordem de Cristo, além de capitão mor das armadas das naus e galeões de socorro e capitão general das armadas de alto bordo dos mares do Estado da Índia. ${ }^{62}$ A casa dos Botelho encontrava-se bem reconhecida e remunerada pelo quadragésimo nono governador da Índia. ${ }^{63}$

Mais que isso até. Nas ações empreendidas por Nuno Álvares Botelho, o qual chegou aos mais altos ofícios de governança na Índia, perpetuava-se uma cultura política e de gênero imperial de valorização de um perfil masculino específico existentes desde os tempos de Francisco Botelho, que foi estribeiro mor do Rei e capitão em Tânger, além de pai de Diogo e avô de Nuno. As façanhas que esses homens contaram de si auxiliaram e reforçaram essa configuração ideal masculina.

Embora os comportamentos destoantes não anulassem as identidades de gênero e não interditassem a forma de se verem como homens e por outros homens, existiram múltiplas subjetividades, experiências, imagens e representações que assinalaram o quão complexas eram essas masculinidades postas em jogo por esses homens, e muitos outros, que atuaram em nome do Monarca na expansão e manutenção do Império ultramarino.

No engrandecimento de sua casa nobre ideal, Diogo Botelho, intencionalmente, esqueceu de mensurar outros acontecimentos, tidos como 
não nobres, ocorridos no espaço físico de sua casa e envolvendo a física de outros corpos. Mas o silêncio, que ocultou desejos, vontades e pensamentos destoantes, foi rompido. O retorno do recalcado, desvelado através da fala de Fernão Rodrigues, reitera a nossa percepção acerca da qualidade heterogênea das masculinidades plurais na América portuguesa e sobre a imprevisibilidade, contingência e historicidade das relações de gênero que aqui nos esforçamos brevemente em discutir. 


\begin{tabular}{|c|c|c|c|c|c|c|c|}
\hline Seq. & Indivíduo & Idade & $\begin{array}{l}\text { Qualificação } \\
\text { social }\end{array}$ & Seq. & Indivíduo & Idade & $\begin{array}{l}\text { Qualificação } \\
\text { social }\end{array}$ \\
\hline 1 & $\begin{array}{l}\text { Agostinho } \\
\text { Ferreira }\end{array}$ & $?$ & $\begin{array}{l}\text { solteiro, filho de } \\
\text { tabelião }\end{array}$ & 22 & Francisco & $?$ & $\begin{array}{l}\text { Escravo de } \\
\text { Felipe Thomás }\end{array}$ \\
\hline 2 & $\begin{array}{l}\text { André Pereira } \\
\text { Sarmento }\end{array}$ & $?$ & Cônego & 23 & João & 15 & $\begin{array}{l}\text { Natural de } \\
\text { Peniche }\end{array}$ \\
\hline 3 & Anrique & 25 & Flamengo, casado & 24 & João de tal & $?$ & $\begin{array}{l}\text { Guarda do ex- } \\
\text { governador }\end{array}$ \\
\hline 4 & $\begin{array}{l}\text { Antônio } \\
\text { Galvão }\end{array}$ & 28 & $\begin{array}{l}\text { Criado do ex- } \\
\text { governador, } \\
\text { casado }\end{array}$ & 25 & $\begin{array}{l}\text { João } \\
\text { d'Albuquerque }\end{array}$ & $?$ & $\begin{array}{l}\text { Cristão velho } \\
\text { criado do } \\
\text { desemb. Antão } \\
\text { de Mesquita }\end{array}$ \\
\hline 5 & $\begin{array}{l}\text { Antônio } \\
\text { Gonçalves }\end{array}$ & $?$ & $\begin{array}{l}\text { Carreiro de } \\
\text { Mosteiro }\end{array}$ & 26 & João Fernades & 23 & $\begin{array}{l}\text { Mulato forro, } \\
\text { solteiro }\end{array}$ \\
\hline 6 & $\begin{array}{l}\text { Antônio } \\
\text { Pereira }\end{array}$ & 19 & Estudante & 27 & Jorge Moniz & 27 & $\begin{array}{l}\text { Cristão novo, } \\
\text { estudante de } \\
\text { filosofia }\end{array}$ \\
\hline 7 & Antônio Roiz & $?$ & $\begin{array}{l}\text { Criado de Felipe } \\
\text { Thomás }\end{array}$ & 28 & $\begin{array}{l}\text { Joseph } \\
\text { Fernandes }\end{array}$ & 18 & $\begin{array}{l}\text { Serviçal, } \\
\text { multato }\end{array}$ \\
\hline 8 & $\begin{array}{l}\text { Baltazar } \\
\text { Álvares }\end{array}$ & 21 & Solteiro & 29 & Luiz Correia & $?$ & Mameluco \\
\hline 9 & $\begin{array}{l}\text { Baltazar } \\
\text { Marinho }\end{array}$ & $?$ & $\begin{array}{l}\text { Capelão da Ermita } \\
\text { de Itapoã }\end{array}$ & 30 & Manuel & 14 & $\begin{array}{l}\text { Filho de } \\
\text { Magdalena } \\
\text { Gois, viúva }\end{array}$ \\
\hline 10 & Batista & $?$ & $\begin{array}{l}\text { Cozinheiro do } \\
\text { governador Vasco } \\
\text { de Souza Pacheco }\end{array}$ & 31 & $\begin{array}{l}\text { Manoel da } \\
\text { Maia }\end{array}$ & 40 & $\begin{array}{l}\text { Cristão novo, } \\
\text { dono de um } \\
\text { trapiche de } \\
\text { melado, casado }\end{array}$ \\
\hline 11 & Bento & 16 & Escravo cirurgião & 32 & Manoel Canal & $?$ & Clérigo \\
\hline 12 & Bento Correia & & $\begin{array}{l}\text { Solteiro, vulgo "o } \\
\text { Calambauzinho" }\end{array}$ & 33 & $\begin{array}{l}\text { Martim } \\
\text { Carvalho } \\
\end{array}$ & $?$ & Fidalgo \\
\hline 13 & Boa Viagem & $?$ & $\begin{array}{l}\text { Estudante filho de } \\
\text { Ruivo }\end{array}$ & 34 & Miguel & $?$ & $\begin{array}{l}\text { Primo de } \\
\text { Duarte } \\
\text { Fernades }\end{array}$ \\
\hline 14 & Diogo Batista & 18 & $\begin{array}{l}\text { Cozinheiro e } \\
\text { Mestre Sala do } \\
\text { Conde d'Anhauer, } \\
\text { criado do } \\
\text { Governador da } \\
\text { Bahia, casado }\end{array}$ & 35 & $\begin{array}{l}\text { Miguel da } \\
\text { Fonseca }\end{array}$ & $?$ & $\begin{array}{l}\text { Cristão novo, } \\
\text { mercador, } \\
\text { primo de } \\
\text { Duarte } \\
\text { Fernandes }\end{array}$ \\
\hline 15 & $\begin{array}{l}\text { Diogo } \\
\text { Botelho }\end{array}$ & 47 & $\begin{array}{l}\text { Governador geral } \\
\text { do Estado do } \\
\text { Brasil }\end{array}$ & 36 & Nicolau Soares & 25 & $\begin{array}{l}\text { Capitão da } \\
\text { guarda do } \\
\text { governador }\end{array}$ \\
\hline 16 & $\begin{array}{l}\text { Diogo da } \\
\text { Silva }\end{array}$ & 25 & $\begin{array}{l}\text { Lavrador de } \\
\text { canas, almoxaride } \\
\text { e almocreve, } \\
\text { solteiro, criado do } \\
\text { Governador Geral }\end{array}$ & 37 & Pascoal Soares & $?$ & $\begin{array}{l}\text { Filho de } \\
\text { Magdalena } \\
\text { Gois, viúva }\end{array}$ \\
\hline 17 & $\begin{array}{l}\text { Duarte } \\
\text { Fernandes }\end{array}$ & 18 & $\begin{array}{l}\text { Serviçal do mestre } \\
\text { de navio Fco. } \\
\text { Leitão, solteiro }\end{array}$ & 38 & Pero Garcia & 48 & $\begin{array}{l}\text { Dono de } \\
\text { Bento (escravo } \\
\text { cirurgião) e de } \\
4 \text { engenhos }\end{array}$ \\
\hline 18 & Eliseu Lopes & 40 & Cristão velho & 39 & Pero Luiz & $?$ & Confeiteiro \\
\hline
\end{tabular}




\begin{tabular}{|c|l|c|l|l|l|l|l|}
\hline 19 & $\begin{array}{l}\text { Felipe } \\
\text { Thomás }\end{array}$ & $?$ & $\begin{array}{l}\text { Cristão novo, } \\
\text { graduado em } \\
\text { Cânones em } \\
\text { Coimbra, casado, } \\
\text { possuía trinta } \\
\text { escravos, 2 casas e } \\
\text { canavial }\end{array}$ & 40 & Pero Mendes & 25 & $\begin{array}{l}\text { Serviçal } \\
\text { de Simão } \\
\text { Fragoso, } \\
\text { mestres de } \\
\text { primeiras } \\
\text { letras }\end{array}$ \\
\hline 20 & $\begin{array}{l}\text { Fernão } \\
\text { Rodrigues de } \\
\text { Sousa }\end{array}$ & 25 & $\begin{array}{l}\text { Pajem do ex- } \\
\text { governador geral, } \\
\text { cavaleiro fidalgo, } \\
\text { casado }\end{array}$ & 41 & Pero Nunes & 18 & Cristão novo \\
\hline 21 & $\begin{array}{l}\text { Francisco } \\
\text { de Sampaio } \\
\text { Aranha }\end{array}$ & 35 & $\begin{array}{l}\text { Cristão velho, } \\
\text { mercador, casado }\end{array}$ & & \\
\hline
\end{tabular}

\section{NOTAS}

1 BICALHO, Maria Fernanda Baptista. Dos "Estados nacionais" ao "sentido da colonização": história moderna e historiografia do Brasil colonial. In: ABREU, Martha; SOIHET, Raquel; GONTIJO, Rebeca (orgs.). Cultura política e leituras do passado: historiografia e ensino de história. Rio de Janeiro: Civilização Brasileira, 2007.

2 Sugerimos a leitura do trabalho feito por Loureiro, onde há uma ótima sistematização dos estudos em torno do debate sobre "Sistema Colonial" e "Império Ultramarino". LOUREIRO, Marcello José Gomes. "Sistema Colonial ou "Império Português"? Batalhas Historiográficas e História Militar. Comunicação apresentada em painel historiográfico no XXXVII Congresso Internacional de História Militar, 2011.

3 Para Almeida as emoções e os sentimentos qualificados e atribuídos diferencialmente para homens e mulheres seriam construções culturais que remeteriam ao aspecto de ser "feito com gênero" do inglês engendered. ALMEIDA, Miguel Vale de. Senhores de si: uma interpretação antropológica da masculinidade. Lisboa: Fim de século, 1995.

4 Collecção Chronologica de Leis Extravagantes, Posteriores à Nova Compilação das Ordenações do Reino, Publicadas em 1603. Decreto, em que se mandou, que se prendessem todos os vadios, que se achassem, para irem servir nas galés. 1639. Tomo I, p. 78.

5 Ibidem. Decreto, em que se determinou, que nas Igrejas não falassem homens com mulher às portas, ou nos adros delas, debaixo de penas arbitrárias, segundo excesso. 1657. Tomo I, p. 134.

6 BNPA, Resolução do rei [D. Filipe II], ao Conselho da Índia, referente à consulta sobre o caso da morte de Roque de Andrade Caminha, morador que foi na vila de Olinda, capitania de Pernambuco; ordena que se passe carta ao ouvidor-geral para que vá à dita vila e advogue a si a devassa que se tirou da morte, prendendo os culpados que arrancaram dentro da igreja e alpendre dela em favor de Duarte de Albuquerque, que consta ser o matador, e os que a cercaram com armas favorecendo os delinquentes, e se envie os presos para a cadeia. Cód. 51-VII-15, fl. 30v, 14/01/1605.

7 As Ordenações Afonsinas foram elaboradas durante o século XV nos reinados de D. João I, D. Duarte e D. Afonso V. Atuaram na sua feitura o cavaleiro João Mendes, Corregedor da Corte e doutor Ruy Fernandes, do Conselho do Rei, além de outros compiladores e jurisconsultos. Este primeiro código teve vigência de 1446 a 1513. Quanto às Ordenações Manuelinas, existiram duas edições (1514-6 e 1521) que vigoraram até a ascensão do Código Filipino em 1603. A sua elaboração iniciada em 1501 ficou a cargo de Rui Boto, Rui da Grá e João Cotrim. Ordenações do Senhor Rey Dom Affonso V do Reino 
de Portugal. Lisboa: [s.n.], 1446. Prefação, pp.I-XXXI. [Edição fac-similar realizada pelo Instituto de História e Teoria das Ideias da Faculdade de Letras de Coimbra].

8 HESPANHA, António Manuel. A monarquia: a legislação e os agentes. In: MATTOSO, José (dir.); MONTEIRO, Nuno Gonçalo (coord.). História da Vida Privada em Portugal: a Idade Moderna. Lisboa: Círculo de Leitores, 2011.

9 Referimo-nos aqui à missiva régia que tratava da festa do Cerimonial Romano na Procissão de Corpus Christi na cidade do Porto. Nesse documento o Rei respondia às queixas do bispo orientando que o Santíssimo Sacramento fosse debaixo do pálio para evitar a indecência e que a procissão seguisse pela Rua Nova, a melhor daquela cidade, para evitar as danças que ocorriam no antigo trajeto. Collecção Chronologica de Leis Extravagantes (1603-1612), Carta régia de 15/05/1607, p. 134.

10 “[...] a masculinidade hegemônica é um modelo cultural ideal, que, não sendo atingível por praticamente nenhum homem, exerce sobre todos os homens um efeito controlador, através da incorporação, da ritualização das práticas da sociabilidade quotidiana e de uma discursividade que exclui todo um campo emotivo considerado feminino; [...] a masculinidade não é simétrica da feminilidade, na medida em que as duas se relacionam de forma assimétrica, por vezes hierárquica e desigual. A masculinidade é um processo construído, frágil, vigiado, como forma de ascendência social que pretende ser". ALMEIDA, Op. cit., p. 17.

11 Para o desenvolvimento desta proposição estabelecemos proximidade com a teoria lacaniana quanto às suas considerações sobre o Eu, principalmente na edificação das noções de Eu Ideal e Ideal do Eu e da concepção de Estado do Espelho. Cf. LACAN, Jacques. Escritos. Rio de Janeiro: Jorge Zahar, 1998.

12 Referimo-nos aqui a obra Leal Conselheiro e Livro da Ensinança de Bem Cavalgar toda sella, escritos pelo senhor Dom Duarte, Rei de Portugal e do Algarve e Senhor de Ceuta. Lisboa: Typographia Rollandiana, 1843.

$13 C f$. BARROS, João de. Panegíricos. Lisboa: Livraria Sá da Costa, 1943.

14 MAGALHÃES, Joaquim Romero (coord.). História de Portugal: no alvorecer da modernidade (1480-1620). Portugal: Estampa,1997. Vol. 3.

15 BOURDIEU, Pierre. A dominação masculina. Rio de Janeiro: Bertrand Brasil, 1999.

16 GAY, Peter. Freud para historiadores. Rio de Janeiro: Paz e Terra, 1989a. p. 142.

17 Idem. Freud: uma vida para o nosso tempo. Tradução de Denise Bottmanns. São Paulo: Cia. das Letras, 1989b. p. 496.

18 HESPANHA, Op. Cit., p. 14.

19 O Livro I dispõe dos Regimentos dos Magistrados dos e Oficiais de Justiça; o Livro II trata das relações entre Igreja e Estado; o Livro III versa sobre o processo civil e criminal; o Livro IV envereda nos direitos das famílias, das coisas, das obrigações e das sucessões.

20 Código Filipino, ou, Ordenações e Leis do Reino de Portugal: recopiladas por mandato d' el - Rei D. Filipe I. Ed. fac-similar da $14^{a}$ ed., segundo a primeira, de 1603, e a nona, de Coimbra, de 1821. Lisboa: Tipografia do Instituto Filomático, 1870, pp. 1315-1316.

21 BRASIL. Ministério da Educação e Saúde. Biblioteca Nacional. Registro de Provisões da Casa da Moeda da Bahia 1775. Documentos Históricos. Registro da carta de doação e sucessão por que Sua Majestade faz mercê a Manuel Garcia Pimentel da capitania do Espírito Santo, para que a logre e possua assim como a teve e logrou e possuiu seu pai, Francisco Gil de Araújo, assim e da maneira que se expressa neste registro. 06/07/1674, pp. 28-9.

22 A lógica de valorização dos indivíduos por meio do cultivo da memória ou da desvalorização em virtude de sua corrupção pode ser visualizada na Carta de Confirmação de Doação da Capitania de São Jorge dos Ilhéus, onde se ordenou a preservação e perpetuação do nome e brasão da família Figueiredo: Item por bem por nisso fazer mercê e ficar memória dele que todos os seus sucessores pessoas a que a 
dita capitania vier se chamem de Figueiredo, sob pena de a que se não chamar de Figueiredo perder a dita capitania e governança e não poder em maneira alguma suceder nela a qual capitania e governança por esse mesmo feito passará logo a outro sucessos a que de direito pertenceria se o tal que isto assim não cumprir fosse morto e serão assim mesmo obrigados os ditos seus sucessores a trazer as armas dos Figueiredos e esta mercê lhes faço como Rei e Senhor destes Reinos e assim como governador e perpétuo administrador que sou da Ordem e Cavalaria do Mestrado de Nosso Senhor Jesus Cristo [...]. BRASIL. Ministério da Educação e Saúde. Biblioteca Nacional. Registro de Provisões da Casa da Moeda da Bahia 1775. Documentos Históricos. Registro de uma petição e despachos por que se manda registrar a doação de Dom Luís Inocêncio de Castro Almirante de Portugal que Sua Majestade lhe fez da capitania dos Ilhéus e sua anexas. 27/08/1714, p. 173.

23 Código Filipino, ou, Ordenações e Leis do Reino de Portugal [...], p. 1153, tít. XIII. Do crime de Lesa Majestade.

24 Ibidem, p. 1162, tít. XIII.

25 CARVALHO, Joaquim Ramos de. Confessar e devassar: a Igreja e a vida privada da Época Moderna. In: MATTOSO, José (dir.); MONTEIRO, Nuno Gonçalo (coord.). História da Vida Privada em Portugal: a Idade Moderna. Lisboa: Círculo de Leitores, 2011.

26 Código Filipino, ou, Ordenações e Leis do Reino de Portugal [...], p. 1141, tít. I.

27 Sobre essa questão ver o intenso debate traçado entre Luiz Mott e Ronaldo Vainfas. Grosso modo e sem querer encerrar a questão de maneira simplista, podemos dizer que para o primeiro a sodomia não era heresia, enquanto que Vainfas assinala a possibilidade de alguns pecados, como o de sodomia, terem sido metamorfoseados e assimilados como heresia. MOTT, Luiz. Sodomia não é heresia: dissidência moral e contracultura. In: VAINFAS, Ronaldo; FEITLER, Bruno; LIMA, Lana Lage da Gama (orgs.). A Inquisição em xeque: temas, controvérsias, estudos de caso. Rio de Janeiro: EdUERJ, 2006.

28 BOSWELL, John. Cristianismo, tolerancia social y homosexualidad. Barcelona: Muchnik, 1992. Pp. 290-291.

29 Ordenações do Senhor Rey Dom Affonso V do Reino de Portugal. Lisboa: [s.n.], 1446, Livro V, tít. XVII, pp. 53-4.

30 Ordenações Manuelinas. Lisboa: [s.n.], 1514, Livro V, tít. 12, pp. 47-9. [Edição fac-similar realizada pelo Instituto de História e Teoria das Ideias da Faculdade de Letras de Coimbra].

31 BLUTEAU, Raphael. Vocabulario Portuguez e Latino, Aulico, Anatomico, Architectonico, Bellico, Botanico, Brasilico, Comico, Critico, Dogmatico, etc. [Autorizado com exemplos dos melhores escriptores portuguezes e latinos, e oferecido a el-rey de Portugal D. João V]. Portugal: Universidade de Coimbra, 1728. [Oito volumes]. Vol. VII, 1728, p. 688.

32 No Código Manuelino há referência da alimária no Livro V, tít. XVII $4^{\circ}$, enquanto que no Código Filipino há definição Livro V, tít. XIII§2 ${ }^{\circ}$

33 Jimena Furlani assinala que embora a prática de sexo com animais não seja aceita por muitas sociedades e tenha invenção longínqua como tabu, nunca deixou de ocorrer na humanidade. Para ela, duas matrizes de pensamento auxiliaram na construção do tabu acerca da zoofilia: a mitologia grega com a lenda do minotauro e o Livro do Levítico "que descreve a Santidade do Casamento, em relação ao homem [afirmando] que 'nem te deitarás com um animal para te contaminares com ele' (18:23) [e] 'se um homem tiver coito com um animal, será punido de morte, matareis também o animal' (20:25)" FURLANI, Jimena. Mitos e tabus da sexualidade humana: subsídios ao trabalho em educação sexual. Belo Horizonte: Autêntica, 2003. P. 116.

34 O Código Manuelino traz referência sobre a alimária no Livro V, tít. XVII§ $4^{\circ}$, enquanto que no Código Filipino há definição no Livro V, tít. XIII§6.

35 Collecção Chronologica de Leis Extravagantes (1603-1612), Carta de Lei de 12/10/1606 - Contra os que cometerem o Pecado de Mollicie, p. 1606. 
36 De acordo com Monteiro, o envio de comitivas às partes do Brasil pela Inquisição portuguesa significou uma nova etapa de expansão após a consolidação dos tribunais inquisitoriais em Portugal que funcionavam desde 1540: "O objetivo seria, a partir de então, garantir o mesmo nos territórios portugueses do além mar, ou seja, nas colônias americana e africanas. A forma encontrada pelo Tribunal Inquisitorial de Lisboa [...] foi a realização de investigações de fé através de uma comitiva oficial do Santo Ofício". MONTEIRO, Lucas Maximiliano. O Livro das Confissões da Bahia e suas possibilidades de pesquisa: uma análise das narrativas dos cristãos-novos (1591-1592). In: IX Encontro Estadual de História, ANPUH, Rio Grande do Sul, 2008. Anais do IX Encontro Estadual de História, ANPUH, Rio Grande do Sul, 2008. Disponível em: http://www.eeh2008.anpuh-rs.org.br/resources/content/ anais/1212335949 ARQUIVO_OLivrodasConfissoesdaBahiaesuas possibilidadesdepesquisaumaanal isedasnarrativasdoscristaos-novos\%281591-1592\%29.pdf. Acesso em 09/01/2013.

37 MOTT, Luiz. Homossexuais da Bahia: dicionário biográfico (séculos XVI-XIX). Salvador: Gripo Gay da Bahia, 1999. Pp. 44 e 45.

38 SERRÃO, Joaquim Veríssimo. Do Brasil Filipino ao Brasil de 1640. São Paulo: Companhia Editora Nacional, 1968.

39 Sobre as divergências entre o ouvidor geral e o provedor mor encontramos registrada na data de 17/01/1597 referência a uma "Carta do bispo D. Pedro de Castilho [vice-rei de Portugal] ao rei [Filipe II], com informações acerca do procedimento do ouvidor-geral do Brasil, Martim Leitão, de induzir testemunhas falsas contra Martim Carvalho". BNPA, Códice 51-VIII-16, n. 54, fl. 10-11v.

40 Arquivo Nacional da Torre do Tombo (ANTT), Chancelaria de Filipe II, Livro 9, fl. 234v-235v, Carta de nomeação de Governador Geral do Estado do Brasil, fl. 234v-235v.

41 Certidão dos oficiais [juízes, vereadores e procurados] da Câmara de Olinda. RIHGB, Rio de Janeiro, Tomo LXXIII, Parte I, pp. 25-29, 1910, p. 27. (28/03/1603). [Imprensa Nacional].

42 Carta testemunhável... RIHGB, Rio de Janeiro, Tomo LXXIII, Parte I, pp. 58-172, 1910, p. 80. (26/09/1603). [Testemunho do alferes Duarte Teixeira].

43 Certidão passada pelos oficiais [juízes e vereadores] da Câmara de Salvador. RIHGB, Rio de Janeiro, Tomo LXXIII, Parte I, pp. 29-33, 1910, p. 29. (20/12/1607). [Imprensa Nacional].

44 Carta testemunhável. RIHGB, Rio de Janeiro, Tomo LXXIII, Parte I, pp. 58-172, 1910, p. 66. (26/09/1603). [Imprensa Nacional].

45 ANTT, Tribunal do Santo Ofício (TSO), Inquisição de Lisboa (IL) (1536-1821), Registros de Visitações (n. 38) (1560-1775), Livro das confissões e reconciliações que se fizeram na visitação do Santo Ofício na cidade do Salvador da Baía de Todos os Santos, do Estado do Brasil (n. 783), fls. 24v-27v, fl. 26v.

46 A Primeira Visitação do Santo Ofício ao Brasil ocorreu entre os anos de 1591-1595 e foi originada pela presença do inquisidor Heitor Furtado de Mendonça. O Arquivo Nacional da Torre do Tombo (ANTT) possui um fundo específico denominado Tribunal do Santo Ofício integrado por documentos das diferentes partes do Reino que datam de 1536-1821. Ali é possível encontrar "correspondência com o Conselho Geral, com os tribunais de Coimbra e de Évora e com as inquisições espanholas; autos da fé; bens confiscados; decretos de prisão; despachos e ordens do Conselho Geral; cadernos do promotor, de reduzidos, nefandos e solicitantes; nomeação dos ministros e oficiais; petições para ajudas de custo, para aposentadoria, para redução de estrangeiros; processos de acusados de heresia; visitações; documentos relativos à atividade do Juízo Fisco." As fontes referentes às visitações ao Brasil estão agrupadas com outros registros e albergadas na série "Registro de Visitações (1560/1775), n. 38". FARINHA, Maria do Carmos Jasmins Dias. Os Arquivos da Inquisição. Lisboa: ANTT, 1990.

47 ANTT, Chancelaria de Filipe I, Livro 12, fl. 234.

48 ANTT, TSO, IL, Registros de Visitações, Livro das confissões e reconciliações que se fizeram na visitação do Santo Ofício na cidade do Salvador da Baía de Todos os Santos, do Estado do Brasil, fls. $24 \mathrm{v}-27 \mathrm{v}$, fl. $24 \mathrm{v}$. 
49 ANTT, TSO, IL, Registros de Visitações, Livro das confissões e reconciliações que se fizeram na visitação do Santo Ofício na cidade do Salvador da Baía de Todos os Santos, do Estado do Brasil, fls. $24 \mathrm{v}-27 \mathrm{v}$, fl. $26 \mathrm{v}$.

50 Todas as idades fazem referência ao ano de 1604 .

51 ANTT, TSO, IL, Registros de Visitações, Livro das confissões..., fls. 24v-27v, fl. 26.

52 Segundo Ferreira Neto (2009, p. 1) “A partir de 1850, os manuais de psiquiatria elencaram várias formas de comportamentos chamados de perversões. A primeira lista incluía: incesto, homossexualidade, zoofilia, pedofilia, pederastia, fetichismo, sadomasoquismo, transvestismo, narcisismo, autoerotismo, corpofília, necrofília, exibicionismo, voyeurismo, mutilações sexuais. Esta lista foi modificada inúmeras vezes, com acréscimos e substituições, até que, em 1995, o Manual Diagnóstico e Estatístico de Transtornos Mentais (DMS-IV-TM) suprimiu os conceitos de perversões e homossexualidade, chamadas agora de parafílias, apelando de novo ao grego, com o sentido de 'amores paralelos, à margem'."

53 ANTT, TSO, IL, Registros de Visitações, Livro das confissões..., fls. 24v-27v, fl. 25.

54 ANTT, TSO, IL, Registros de Visitações, Livro das confissões..., fls. 24v-27v, fl. 26v.

55 Ibidem.

56 Jimena Furlani procurando desmistificar muitos mitos em torno da sexualidade humana, esclareceu o seguinte acerca do sexo anal: "Muitas pessoas, mulheres ou homens, podem alcançar o orgasmo pelo estímulo das terminações nervosas da região anal. Estas terminações são ramificações dos nervos que emergem da coluna sacral, responsáveis pelas transmissões eróticas sensitivas. Trata-se do mesmo conjunto de estruturas sensitivas-neurais responsáveis pela enervação do pênis, do clitóris e de toda a região pudenda. [...] As fibras sensitivas e eróticas (região externa do ânus), aí existentes, quando estimuladas, podem ser extremamente prazerosas para muitas pessoas e inibitórias para outras. Já foram observadas contrações involuntárias do ânus, aproximadamente do mesmo índice da plataforma orgástica feminina e da uretra do pênis, a intervalos de 0,8 segundos”. FURLANI, Op. Cit., p. 118.

57 ANTT, TSO, IL, Registros de Visitações (1560/1775).

58 Osvaldo Bazán, em seu trabalho de síntese sobre a história da homossexualidade na Argentina, aponta a discussão tomada pelos espanhóis em torno da sodomia, assinalando a ocorrência da prática por índios e europeus, no período colonial. Georges Vigarello, abordou a história da violação na França entre os séculos XVI-XX também assinalou o registro de vários casos de sodomia; e John Boswell, em trabalho mais amplo, analisou como a homossexualidade foi tratada pelo cristianismo ao longo da história ocidental, desde Roma à Idade Média. Abordou situações interessantes como a depreciação feita por Filipe IV, rei da França, entre os séculos XIII e XIV, em relação aos cavaleiros templários ao acusá-los de sodomia com o intuito de destituí-los de poder: "Se dizia que os templários estavam aliados com o demônio, que adoravam a Mahoma, que parodiavam a missa, que sodomizavam regularmente aos noviços, que toleravam os atos homossexuais durante suas cerimônias sagradas" BOSWELL, Op. Cit., p. 316 . Muitos foram os cavaleiros mortos e enviados à fogueira. Alguns heróis não sobreviveriam à acusação do pecado nefando. Cf. BAZÁN, Osvaldo. Historia de la homosexualidad en la Argentina. Buenos Aires: Mares, 2010; VIGARELLO, Georges. História da Violação: séculos XVI-XX. Lisboa: Estampa, 1998.

59 ANTT, TSO, IL, Registros de Visitações, Livro das confissões...., fls. 24v-27v, fl. 27v.

60 REPÚBLICA PORTUGUESA. Ministério das Colônias. Nuno Álvares Botelho: capitão geral das armadas de alto bordo e governador da Índia. Lisboa: Divisão de Publicações e Biblioteca Geral das Colônias, 1940.

61 Ibidem. Cartel de Desafio [Traslado do quartel em que o capitão general Nuno Álvares Botelho desafiou com a sua armada as de Inglaterra e Holanda, que estavam no poço de Surrate], pp. 215-6.

62 REPÚBLICA PORTUGUESA. Ministério das Colônias. Nuno Álvares Botelho: capitão geral das armadas de alto bordo e governador da Índia. Lisboa: Divisão de Publicações e Biblioteca Geral das Colônias, 1940, pp. 215-6. Cartel de Desafio [Traslado do quartel em que o capitão general Nuno Álvares 
Revista Esboços, Florianópolis, v. 23, n. 35, p. 61-89, set. 2016.

Botelho desafiou com a sua armada as de Inglaterra e Holanda, que estavam no poço de Surrate].

63 MACHADO, Diogo Barbosa. Biblioteca Lusitana. Tomo I. Coimbra: Atlântica, 1965, p. 639.

Artigo recebido em abril de 2016. Aceito em julho de 2016. 